Klin Wochenschr (1988) 66:361-364

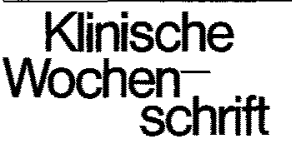

(C) Springer-Verlag 1988

\title{
Nonhypnotic Low-Dose Etomidate for Rapid Correction of Hypercortisolaemia in Cushing's Syndrome
}

\author{
B. Allolio ${ }^{1}$, H.M. Schulte ${ }^{2}$, D. Kaulen ${ }^{1}$, M. Reincke ${ }^{1}$, C. Jaursch-Hancke ${ }^{1}$, and W. Winkelmann ${ }^{1}$ \\ ${ }^{1}$ Medizinische Universitätsklinik II, Köln-Merheim and ${ }^{2}$ I. Medizinische Universitätsklinik, Kiel
}

\begin{abstract}
Summary. We determined the adrenostatic potential of low-dose nonhypnotic etomidate in six patients with Cushing's syndrome (ectopic Cushing's syndrome, $n=2$; Cushing's disease, $n=3$; bilateral adrenal adenoma, $n=1$ ). Etomidate was given as a continuous infusion for $32 \mathrm{~h}$ in a dose of $2.5 \mathrm{mg} /$ $\mathrm{h}(n=5)$ or $0.3 \mathrm{mg} / \mathrm{kg} / \mathrm{h}(n=3)$, respectively. Saline was given during a control period. The responsiveness to exogenous ACTH was studied during placebo and 7 and $31 \mathrm{~h}$ after commencing etomidate by administration of $250 \mu \mathrm{g}$ 1-24 ACTH i.v. Etomidate $(2.5 \mathrm{mg} / \mathrm{h})$ led to a consistent decrease in serum cortisol in all patients from a mean of $39.4 \pm 13.3$ to $21.1 \pm 5.7 \mu \mathrm{g} / \mathrm{dl}$ after $7 \mathrm{~h}(P<0.05$ compared with placebo). After $24 \mathrm{~h}$ cortisol was reduced further to a mean steady state concentration of $12.3 \pm 5.7 \mu \mathrm{g} / \mathrm{dl}(P<0.05)$. At the end of the infusion period the cortisol increase in response to ACTH was reduced but not abolished. In contrast, a dose of $0.3 \mathrm{mg} / \mathrm{kg} / \mathrm{h}$ etomidate induced unresponsiveness of serum cortisol to exogenous $\mathrm{ACTH}$ within $7 \mathrm{~h}$. However, sedation was observed in two out of three patients at this dose, while during etomidate in a dose of $2.5 \mathrm{mg} / \mathrm{h}$ no side effects were seen. We conclude that low-dose nonhypnotic etomidate reduces serum cortisol to within the normal range in patients with Cushing's syndrome. The possibility to dissociate the adrenostatic effect of etomidate from its hypnotic action, the absence of side effects, and the i.v. route suggest that etomidate in a dose of $0.04-0.05 \mathrm{mg} / \mathrm{kg} / \mathrm{h}$ may become the drug of choice for rapid initial control of hypercortisolism.
\end{abstract}

Key words: Etomidate - Cortisol - ACTH Cushing's syndrome

Abbreviations: $\mathrm{ACTH}=$ adrenocorticotrophic hormone; $\mathrm{CD}=$ Cushing's disease; $C S=$ Cushing's syndrome
During recent years it has been shown that the anesthetic drug etomidate is also a potent adrenostatic agent $[2,3,5,7,8,12,13,17,19]$. Etomidate blocks the cytochrome P450-dependent adrenal enzymes $11 \beta$-hydroxylase and cholesterol-side-chain cleavage enzyme $[3,5,8,12,19]$. Using dispersed guinea-pig adrenal cells, etomidate has been proved to be the most powerful adrenostatic drug available [13]. In this system a mean etomidate concentration of $97 \mathrm{nmol} / 1$ was required for $50 \%$ inhibition of cortisol secretion [13]. This is considerably lower than the target mean plasma concentration of $560 \mathrm{nmol} / 1$ to induce sedation [10]. Accordingly after a single induction dose of etomidate $(0.3 \mathrm{mg} / \mathrm{kg}$ body weight) the adrenocortical blockade lasts several hours $[2,7]$, while the hypnotic action of etomidate rapidly fades. Using low plasma concentrations it should, therefore, be possible to dissociate the adrenostatic action of etomidate from the hypnotic properties of the compound. This was successfully demonstrated in a small number of normal subjects by Engelhardt et al. [6] using a bolus dose of $0.03 \mathrm{mg} / \mathrm{kg}$ body weight followed by a continuous infusion of etomidate at a dose of $0.3 \mathrm{mg} / \mathrm{kg} / \mathrm{h}$.

The aim of the present study was to evaluate the adrenostatic potential of low-dose nonhypnotic etomidate in the treatment of patients with Cushing's syndrome. The efficacy of hypnotic doses of etomidate in reversing hypercortisolemia has been proved recently [9].

\section{Patients and Methods}

A total of six patients with Cushing's syndrome was studied (1 male, 5 females, aged 37 to 54 years). Cushing's syndrome was diagnosed by dexamethasone nonsuppressible serum cortisol, ele- 
Table 1. Clinical data of the six patients with Cushing's syndrome

\begin{tabular}{|c|c|c|c|c|c|c|}
\hline \multirow[t]{2}{*}{ Patient } & \multirow{2}{*}{$\begin{array}{l}\text { Age } \\
\text { (years) }\end{array}$} & \multirow[t]{2}{*}{ Sex } & \multirow{2}{*}{$\begin{array}{l}\text { Body } \\
\text { Weight } \\
(\mathrm{kg})\end{array}$} & \multicolumn{2}{|c|}{ Baseline $(9: 00 \mathrm{~h})$} & \multirow[t]{2}{*}{ Diagnosis } \\
\hline & & & & $\begin{array}{l}\text { Plasma } \\
\text { ACTH } \\
(\mathrm{pg} / \mathrm{ml})\end{array}$ & $\begin{array}{l}\text { Serum } \\
\text { cortisol } \\
(\mu \mathrm{g} / \mathrm{dl})\end{array}$ & \\
\hline 1 & 43 & $M$ & 73.1 & 358 & 22.0 & Ectopic CS \\
\hline 2 & 37 & $\mathrm{~F}$ & 62.4 & 152 & 106.3 & Ectopic CS \\
\hline 3 & 52 & $\mathrm{~F}$ & 68.5 & 21 & 23.8 & $\mathrm{CD}$ \\
\hline 4 & 39 & $\mathrm{~F}$ & 72.8 & 27 & 56.1 & $\mathrm{CD}$ \\
\hline 5 & 54 & $\mathrm{~F}$ & 92.7 & 38 & 39.5 & $\mathrm{CD}$ \\
\hline 6 & 47 & $\mathrm{~F}$ & 74.3 & $<5$ & 28.5 & $\begin{array}{l}\text { Bil. adrenal } \\
\text { adrenoma }\end{array}$ \\
\hline
\end{tabular}

a Studied after unilateral adrenalectomy

$\mathrm{M}$, male; F, female; CS, Cushing's syndrome; CD, Cushing's disease

vated urinary free cortisol, and altered diurnal rhythm of cortisol as assessed by measurements of salivary free cortisol. Two of the six patients suffered from the ectopic ACTH syndrome due to a medullary carcinoma of the thyroid and a carcinoid of unknown primary site with liver metastases, respectively. One patient had bilateral adrenal adenomas and was studied 4 months after unilateral adrenalectomy. The remaining three patients had Cushing's disease. Patient data are given in Table 1.

Protocol: The patients were studied during 3 consecutive days. On day 1 placebo ( $0.9 \%$ saline) was given intravenously over $8 \mathrm{~h}$. On day 2 a continuous infusion of etomidate $(2.5 \mathrm{mg} / \mathrm{h})$ was started at $8: 00 \mathrm{~h}$ and continued until $16: 00 \mathrm{~h}$ of day 3 (infusion period $32 \mathrm{~h} ; n=5$ ). In addition, in three patients ACTH stimulation tests $(250 \mu \mathrm{g}$ 1-24 $\mathrm{ACTH}$ as bolus dose intravenously) were performed at 15:00 h on the 3 consecutive days.

Three patients underwent a similar protocol with the dose of etomidate increased to $0.3 \mathrm{mg} / \mathrm{kg}$ / $\mathrm{h}$. In case of hypnotic side effects the dose of etomidate was reduced by $50 \%$.

Blood samples were collected in hourly intervals from 8:00 $\mathrm{h}$ until 16:00 $\mathrm{h}$ during the 3 days of the study. Serum cortisol and 11-deoxycortisol were measured by radioimmunoassay using commercially available reagents (NEN, Dreieich, DRG Instruments, Marburg, FRG), plasma ACTH was determined by radioimmunoassay [1] after extraction with QUSO $\mathrm{G}_{32}[18]$.

Statistical evaluation was performed using Student's $t$-test for paired data.

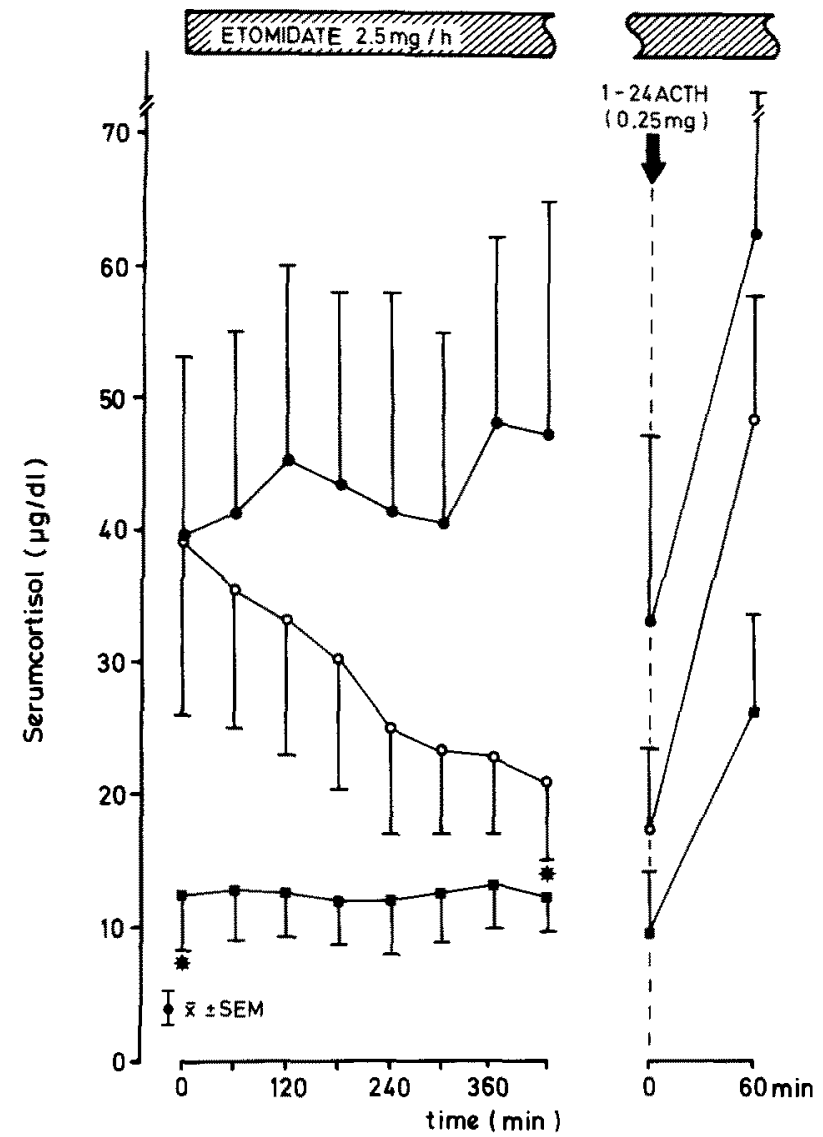

Fig. 1. Basal $(n=5)$ and stimulated $(n=3)$ serum cortisol in Cushing's syndrome during saline $(\bullet \bullet)$, after commencing etomidate $(2.5 \mathrm{mg} / \mathrm{h} ; 0-0)$, and under steady-state conditions $(--)\left({ }^{*} P<0.05\right)$

\section{Results}

Baseline serum cortisol concentrations ranged between 22.0 and $106.3 \mu \mathrm{g} / \mathrm{d} 1$, with the highest concentrations in the patient with ectopic ACTH secretion due to a medullary carcinoma of the thyroid. As expected, no change in serum cortisol levels was observed during administration of saline. After commencing low dose etomidate $(2.5 \mathrm{mg} / \mathrm{h})$ a continuous fall of serum cortisol was observed in all subjects from a mean of $39.4 \pm 13.3$ to $21.1 \pm 5.7 \mu \mathrm{g} / \mathrm{dl}(\bar{x} \pm \mathrm{SEM})$ at $15: 00 \mathrm{~h}(P<0.05)$.

On day 3 serum cortisol was reduced further to $12.3 \pm 5.7 \mu \mathrm{g} / \mathrm{dl}$ at $8: 00 \mathrm{~h}(P<0.05$ compared to placebo) and remained unchanged during the rest of the infusion period, indicating that steadystate conditions had been reached (Fig. 1). Stimulation with $\mathrm{ACTH}$ induced an increase in serum cortisol of $28.6 \pm 7.9 \mu \mathrm{g} / \mathrm{dl}$ during placebo, which was not influenced by an 8 -h infusion of etomidate ( $\Delta$ cortisol: $28.5 \pm 8.3 \mu \mathrm{g} / \mathrm{dl}$ ). However, on day 3 at the end of the infusion period the cortisol in- 


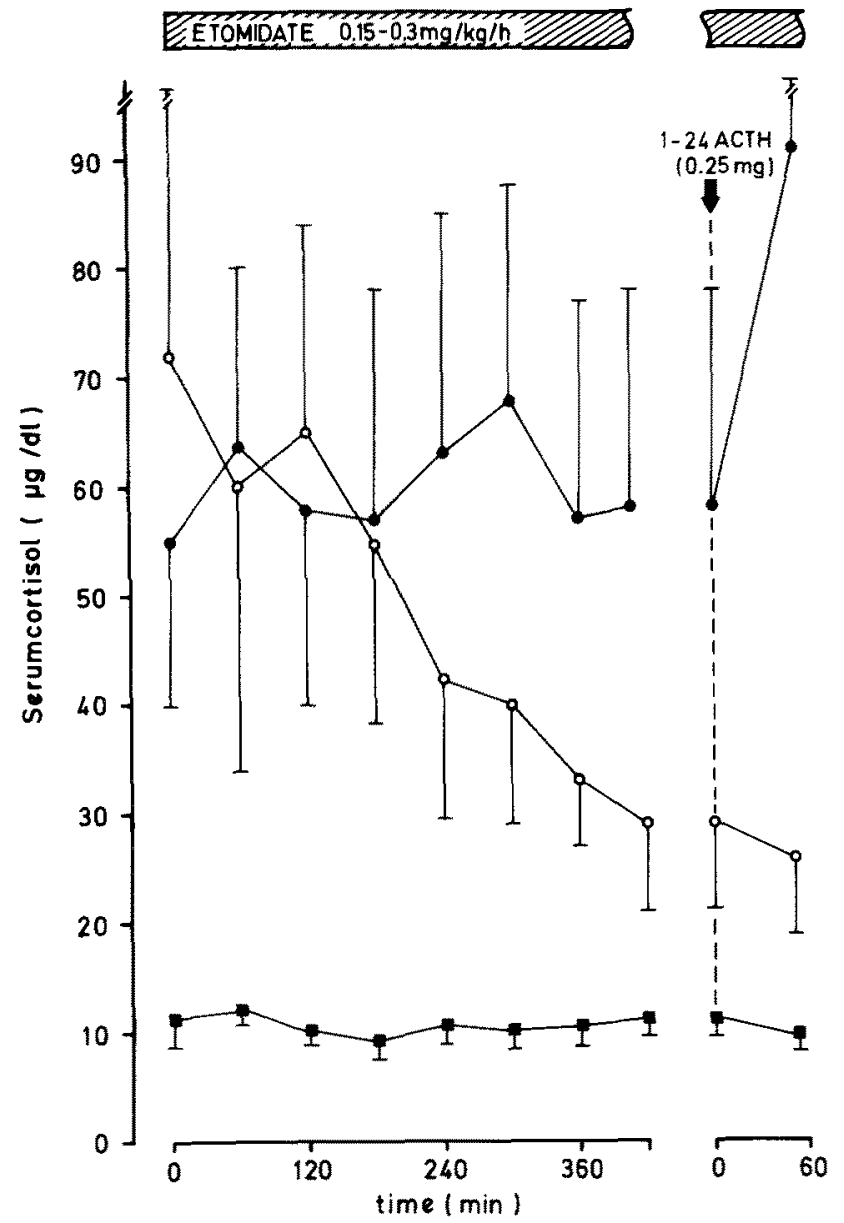

Fig. 2. Basal and stimulated serum cortisol in three patients with Cushing's syndrome during saline ( $\bullet$ ), after commencing etomidate $(0.3 \mathrm{mg} / \mathrm{kg} / \mathrm{h} ; 0-0)$, and under steady-state conditions (0.15-0.3 $\mathrm{mg} / \mathrm{kg} / \mathrm{h}$; - - - $)$

crease after $\mathrm{ACTH}$ was diminished to $13.6 \pm 3.9 \mu \mathrm{g} /$ dl (Fig. 1).

The pattern of the cortisol response to etomidate was very similar when an initial dose of $0.3 \mathrm{mg} / \mathrm{kg} / \mathrm{h}$ was used with a decline from $72.1 \pm 30.4 \mu \mathrm{g} / \mathrm{dl}$ to $29.3 \pm 8.3 \mu \mathrm{g} / \mathrm{dl}$ at $15: 00 \mathrm{~h}$ after the start of etomidate and steady-state concentrations of $11.2 \pm 2.4 \mu \mathrm{g} / \mathrm{dl}$ on day 3 (Fig. 2). However, in contrast to a dose of $2.5 \mathrm{mg} / \mathrm{h}$, the higher dose of etomidate completely blocked the cortisol response to exogenous ACTH (Fig. 2). During administration of $0.3 \mathrm{mg} / \mathrm{kg} / \mathrm{h}$ etomidate a slight sedation was noticed in two of the three patients, which rapidly disappeared after reduction to $0.15 \mathrm{mg} / \mathrm{kg} / \mathrm{h}$. Basal plasma ACTH concentrations ranged from undetectable (in the patient with bilateral adrenal adenoma) to $358 \mathrm{pg} / \mathrm{ml}$. No consistent change of plasma ACTH concentrations was observed in any single patient, in particular no
$\mathrm{ACTH}$ increase was demonstrated in the three patients with Cushing's disease.

Baseline serum 11-deoxycortisol concentrations ranged from 3.8 to $18.3 \mathrm{ng} / \mathrm{ml}$ during placebo and consistently increased during etomidate infusion to a variable extent reaching maximum values between $75 \mathrm{ng} / \mathrm{ml}$ (adrenal adenoma) and $452 \mathrm{ng} /$ $\mathrm{ml}$ (ectopic ACTH syndrome). During $2.5 \mathrm{mg}$ etomidate/h 11-deoxycortisol rose from $9.1 \pm 2.9 \mathrm{ng} /$ $\mathrm{ml}$ at $8: 00 \mathrm{~h}$ of day 2 to $125 \pm 68 \mathrm{ng} / \mathrm{ml}$ at $15: 00 \mathrm{~h}$ of day 3 .

\section{Discussion}

In this study etomidate was successfully employed to correct the hypercortisolemia of Cushing's syndrome without unwarranted hypnotic side effects. Independent of baseline levels cortisol was suppressed to within the normal range with as little as $2.5 \mathrm{mg} / \mathrm{h}$ etomidate. Although the cortisol response to exogenous ACTH was not completely blocked at this dose, no escape of serum cortisol was found, as no increase in endogenous $\mathrm{ACTH}$ secretion occurred.

A failure of ACTH to rise in response to adrenostatic therapy in Cushing's disease has also been observed during administration of ketoconazole, another imidazole derivative [14], as well as during long-term treatment with metyrapone and aminoglutethimide [11]. This phenomenon probably reflects the autonomous nature of $\mathrm{ACTH}$ secretion by the pituitary tumor, rather than a direct suppressive action of these substances at the pituitary level [15].

When etomidate was given in a dose of $0.3 \mathrm{mg} /$ $\mathrm{kg} / \mathrm{h}$, responsiveness of cortisol to exogenous ACTH was rapidly lost, making this dosage at first glance even more attractive for control of hypercortisolemia. However, in contrast to the findings of Engelhardt et al. [6] in normal subjects, sedation was observed in two of the three patients studied. Thus, at this dose only a small margin separates the adrenostatic action of etomidate from its potent hypnotic properties. This was amply demonstrated in another patient with an adrenal adenoma in whom incorrect handling of the more highly concentrated etomidate solution led to a short period of deep sedation. Moreover, for infusion of etomidate at a dose of $0.3 \mathrm{mg} / \mathrm{kg} / \mathrm{h}$ a special preparation of etomidate dissolved in ethanol is necessary, which was introduced only for investigational use in long-term sedation and is not generally available. These difficulties and the observation that steady-state concentrations of cortisol during infusion with etomidate were rather similar 
with the two different dosages make $0.3 \mathrm{mg} / \mathrm{kg} / \mathrm{h}$ etomidate less suitable for treatment of hypercortisolemia.

Etomidate for induction of anesthesia is dissolved in propyleneglycol. Because of possible hematolytic side effects of this solvent, no more than $80 \mathrm{mg}$ of etomidate should be administered within $24 \mathrm{~h}$ according to the guidelines of the manufacturer. Given as a continuous infusion this equals a dose of $3.3 \mathrm{mg} / \mathrm{h}$, which is $33 \%$ higher than the dose successfully used in our study. Thus, the wider margin of safety and the availability suggest that a dose of $80 \mathrm{mg} / 24 \mathrm{~h}(0.04-0.05 \mathrm{mg} / \mathrm{kg} / \mathrm{h})$ should be infused for rapid correction of hypercortisolemia in Cushing's syndrome.

Adrenostatic therapy of Cushing's syndrome is of limited value as in this disease surgical removal of the underlying cause is the ultimate therapeutic goal. However, long-term treatment with adrenostatic agents has been shown to be feasible in a number of studies $[4,11,13,16]$ and may be the treatment of choice for ectopic Cushing's syndrome in the presence of extensive disease [16]. Moreover, clinical improvement achieved by adrenostatic agents may favorably influence the results of later surgery. In the severely ill patient with Cushing's syndrome, rapid control of hypercortisolemia may be mandatory to avoid serious complications due to hypokalemia or psychosis and, thus, be a prerequisite for further management. Here etomidate may become the drug of choice because it is the only adrenostatic agent which can be administered intravenously while lacking the side effects frequently encountered with other adrenostatic agents.

In conclusion, low-dose etomidate has been shown to correct the hypercortisolemia of Cushing's syndrome without hypnotic side effects. As etomidate is the only adrenostatic agent which can be given intravenously it appears to be especially suitable for the initial therapy of the severely ill patient with Cushing's syndrome, in a therapeutic dose of $0.04-0.05 \mathrm{mg} / \mathrm{kg} / \mathrm{h}$.

Acknowledgements: We are grateful to Ms. D. Vollmar, H. Hofmann, and G. Roßbach for skilful technical assistance. High-dose etomidate was a gift of Fa, Janssen, NeuB, FRG

\section{References}

1. Allolio B, Winkelmann W, Hipp FX (1980) Effect of meclastine, an $\mathrm{H}_{1}$-antihistamine, on plasma $\mathrm{ACTH}$ in adrenal insufficiency. Acta Endocrinol 96:98-101

2. Allolio B, Stuttmann R, Leonhard U, Fischer H, Winkelmann $W(1984)$ Adrenocortical suppression by a single induction dose of etomidate. Klin Wochenschr 62:1014-1017
3. Allolio B, Dörr H, Stuttmann R, Knorr D, Engelhardt D, Winkelmann W (1985) Effect of a single bolus of etomidate upon eight major corticosteroid hormones and plasma ACTH. Clin Endocrinol 22:281-286

4. Child DF, Burke CW, Burley DW, Rees LH, Fraser TR (1985) Drug control of Cushing's syndrome. Acta Endocrinol $82: 330-341$

5. De Coster R, Beerens D, Haelterman C, Wouters L (1985) Effects of etomidate on cortisol biosynthesis in isolated guinea-pig adrenal cells: comparison with metyrapone. J Endocrinol Invest 8:199-202

6. Engelhardt D, Stuttmann H, Jacob K, Dörr HG (1986) Influence of low-dose etomidate on adrenal and gonadal steroid hormone secretion in normal men. Acta Endocrinol [Suppl 274] 111:21-22

7. Fragen RJ, Shanks CA, Molteni A, Avram MJ (1984) Effects of etomidate on hormonal responses to surgical stress. Anesthesiology $61: 652-656$

8. Fry DE, Griffiths H (1984) The inhibition by etomidate of the $11 \beta$-hydroxylation of cortisol. Clin Endocrinol $20: 625-629$

9. Gärtner R, Albrecht M, Müller OA (1986) Effect of etomidate on hypercortisolism due to ectopic ACTH production. Lancet $1: 275$

10. Hebron BS, Edbrooke DL, Newby DM, Mather SI (1983) Pharmacokinetics of etomidate associated with prolonged i.v. infusion. Br J Anaesth 55:281-285

11. Jeffcoate WJ, Rees LH, Tomlin S, Jones AE, Edwards CRW, Besser GM (1977) Metyrapone in long-term management of Cushing's disease. Br Med J 2:215-217

12. Kenyon CJ, Young J, Gray CE, Fraser R (1984) Inhibition by etomidate of steroidogenesis in isolated bovine adrenal cells. J Clin Endocrinol Metab 58:947-949

13. Lambert A, Mitchell R, Forst J, Ratcliffe JG, Robertson WR (1983) Direct in vitro inhibition of adrenal steroidogenesis by etomidate. Lancet II:1085-1086

14. Loli P, Berselli ME, Tagliaferri M (1986) Use of ketoconazole in the treatment of Cushing's syndrome. J Clin Endocrinol Metab 63:1365-1370

15. Stalla GK, Stalla J, Huber M, Müller OA (1987) Ketoconazole inhibits cAMP generation and ACTH secretion in rat anterior pituitary cell culture. Acta Endocrinol [Suppl 283] $114: 32-33$

16. Thoren M, Adamson U, Sjöberg HE (1985) Aminoglutethimide and metyrapone in the management of Cushing's syndrome. Acta Endocrinol 109:451-457

17. Vanden Bossche H, Willemsens $G$, Cools W, Bellens D (1984) Effects of etomidate on steroid biosynthesis in subcellular fractions of bovine adrenals. Biochem Pharmacol $33: 3861-3868$

18. Voigt KH, Fehm HL, Reck R, Pfeiffer EF (1974) Spontaneous and stimulated secretion of Quso-extractable immunoassayable ACTH in man. Klin Wochenschr 52:516-521

19. Wagner RL, White PF, Kan PB, Rosenthal MH, Feldman MD (1984) Inhibition of adrenal steroidogenesis by the anesthetic etomidate. N Engl J Med 310:1415-1421

Received: September 7, 1987

Returned for revision: October 27, 1987

Accepted: January 19, 1988

Dr. B. Allolio

Medizinische Klinik

Ostmerheimer Straße 200

D-5000 Köln 91 